\title{
Employment Access and Job Search Channels for Young People in Congo
}

\author{
Michel Okiemy, Sylvaniste Etsiba \\ Laboratoire d'Analyses et d'Etudes Economiques et Sociales (LARES), Faculté des Sciences Economiques, Université Marien \\ Ngouabi, Brazzaville, Congo \\ Email: michel.okiemy@umng.cg, sylvanistetsiba@yahoo.fr
}

How to cite this paper: Okiemy, M., \& Etsiba, S. (2021). Employment Access and Job Search Channels for Young People in Congo. Theoretical Economics Letters, 11, 302-319.

https://doi.org/10.4236/tel.2021.112021

Received: February 23, 2021

Accepted: April 12, 2021

Published: April 15, 2021

Copyright $\odot 2021$ by author(s) and Scientific Research Publishing Inc. This work is licensed under the Creative Commons Attribution International License (CC BY 4.0).

http://creativecommons.org/licenses/by/4.0/

(c) (i) Open Access

\begin{abstract}
The purpose of this paper is to analyze the channels through which young people in Congo access and seek employment. To achieve this goal, we relied on contemporary job search theory. The results obtained from a bivariate probit model on the basis of data from the survey carried out by the "Laboratoire de Recherches et d'Etudes Economiques et Sociales" in 2018 on the employability of young people showed that social networks are the channel through which young people access employment and that the informal sector offers more employment to young people than the formal sector. These results allow us to formulate some implications for economic policies relating to employment access and job search channels in Congo.
\end{abstract}

\section{Keywords}

Access Channels, Employment, Formal, Informal, Young

\section{General Introduction}

According to the United Nations (2017), the world's population will reach 7.6 billion in 2018, of which 60.4 million, or $12.0 \%$, will be unemployed. Moreover, according to the ILO (2019), despite a decrease in the unemployment rate in 2019 (11.8\%, for an unemployed population of 59.1 million), the large youth population will exert strong pressure on the labor market. This pressure will have a strong impact, as paid work is a source of income for the majority of young people worldwide. However, the problems of job searching and access to employment remain a major challenge both theoretically and in reality.

Theoretically, the problems of job searching and access to employment are based on job search theory. In this respect, job search theory became popular in the 1970 s as an alternative to the "standard" neoclassical labor supply theory. 
The neoclassical framework, which was based on the assumption of perfect information, did not consider individuals who were actively looking for work but could not find it to be unemployed. Individual agents had only two options, either to be employed or to be inactive (i.e., not in the labor force). However, the evidence showed that unemployment and its duration were not negligible. This led a group of researchers (Mortensen, 1970; Stigler, 1962; Phelps et al., 1970) to formulate an alternative theory capable of accounting for unemployment, which became known as "job search theory".

The main premise of job search models is that the job search is a dynamic sequential process and that individuals must decide when to stop this process under conditions of uncertainty and imperfect information. Frictional unemployment is a natural consequence of this process. Thus, this theory distills most of the controversies relating to the occupational integration of young people upon leaving the education system. It identifies two modes of job searching and access to employment: the formal mode (North, 1990; Pantoja, 1999) and the informal mode (Granovetter, 1973).

According to the factual perspective, the evidence suggests that in sub-Saharan Africa, informal networks of family and friends are the main channels for job searching. According to Sara and Koné (2014), 41.6\% of young people in five out of eight countries use this mode of access to employment, and spontaneous applications are the second most common mode of access (19.2\%). On the other hand, formal job search channels are used by less than $10 \%$ of unemployed young people who register with agencies. Finally, 15.4\% of young people are registered with an agency to access employment.

The results of the same survey, conducted by the International Labor Office (ILO, 2019), in Congo showed that nearly $72.0 \%$ of unemployed youths turn to family, friends and acquaintances to find work. In addition, $27.5 \%$ of unemployed youth wait for recruitment in the informal sector, and $25.2 \%$ apply in response to an advertisement. Finally, only $7.7 \%$ are registered at an employment agency.

These facts show that despite the choice to turn to family, friends and acquaintances for employment in Africa in general and in the Congo in particular, unemployment rates remain high among young people (30.5\% in the Congo and $4.3 \%$ in African countries). However, the low level of unemployment in Africa does not indicate a well-functioning labor market because for a large part of the African population, unemployment is not an option. Indeed, many people fall victim to downgrading and are forced to accept low-quality, informal jobs to meet their basic needs and escape poverty (ILO, 2019). This situation justifies our focus on the issue of employment access and job search channels.

This concern is all the more important in the context of the Congo, where employment agencies play the role of labor market intermediaries in the search for employment. They are seen as an important factor in analyzing individuals' transition to work. They give young people the opportunity to obtain informa- 
tion on available job opportunities and to benefit from training and projects or programs that can improve their employability. Apart from employment agencies, the search for and access to employment by young people in the Congo is also facilitated by strong or weak social relations. However, these social networks outside the labor market present both positive externalities (knowledge of the behavior of agents, their environment, collective action) and negative externalities (social exclusion, perverse social capital).

In light of the above, the question addressed in this work is posed as follows: what is the most effective way for Congolese youth to find and access employment? The objective of this paper is to analyze the modes of job search and access to employment for Congolese youth to identify those that best facilitate access to the labor market. In light of the work of Granovetter (1973) and Ngassa (2018), we support the hypothesis that the use of social capital facilitates access to employment for Congolese youth.

The rest of the paper is organized as follows: The first section provides a theoretical and empirical review, the second focuses on methodology, the third is concerned with the presentation and interpretation of the results, and the fourth provides a conclusion and implications for economic policy.

\section{Theoretical Review}

Concerns about youth employment and opportunities are consistently at the top of the development agenda in most African countries. The transition from the education system to the labor market, as well as between different employment sectors, is particularly difficult for young Africans (World Bank, 2014). Thus, microeconomic modeling and analysis of the labor market have been the subject of a large body of literature, both theoretical and empirical. The question of modes of access to first employment after training and the role of training systems naturally mainly affects young people leaving the training system in the Congo, even if anyone leaving a training system, whether for an initial or continuing job search, is also concerned.

Job search theory is favored by the majority of neoclassical economists for analyzing the job search phase because it provides information on the influence of certain phenomena in the job search process, such as the costs of searching, the possibility of acquiring information about job offers, the acceptance of "odd jobs", and the influence of the period spent unemployed. A worker knows the distribution of wages offered by firms but does not know exactly which firm offers which wage. He or she uses the period of unemployment to search for an offer that is acceptable in terms of its characteristics.

During this job search, educational attainment appears to be positively correlated with job search intensity, as shown in some work referring to job search theory (Moreau \& Visser, 1991, Wadsworth, 1990). In reality, this theory proposes a new application of the postulate of the rationality of economic agents. Stigler (1962) describes the optimizing calculation used by the labor supplier: as 
long as the marginal cost of the duration of job search is greater than the expected marginal gain, the individual will continue to search.

Job search is an investment in the search for information in the neoclassical sense, the return on which is obtaining a rewarding job. The efficiency of the effort devoted to the research activity is linked to the cost of prospecting. Many research activities can be performed by the unemployed person, including consulting classified ads, sending out mail, obtaining information from specialized organizations, contacting friends, activating networks, and traveling to meet potential employers (Bessy, Marchal, \& Rieucau, 2007). These search methods can be classified into two main and opposing groups: the so-called formal modes, which include public and private institutional intermediaries, and the informal methods, which stem from the mobilization of social ties. In addition to these two major search methods, there are also spontaneous applications, which are formally characterized by market intermediation.

Formal search modes bring together public and private intermediaries. They ensure a broader search across a large number of job offers and allow the accumulation of standardized information on salary, contract type, and company size. Institutional intermediaries are the public or private agencies that act as hiring intermediaries, and it is in this sense that Bull et al. (1987) demonstrate that institutional intermediaries make it possible to increase the profitability of prospecting by partially reducing job search costs. On the basis of this analysis, Baudry (1994) supports the effectiveness of intermediaries in selecting graduates with training that matches the needs of companies.

However, informal modes of research or social networks favor intensive prospecting and provide more precise information on working conditions and the tasks to be performed (Rees, 1966). These modes place more emphasis on prospecting through the social network. For example, Clark (1999) emphasizes the relevance of individual characteristics, particularly levels of education and work experience. On the other hand, Marry (1992) argues that the most highly educated job seekers use market modes and social networks; she also specifies that human capital is positively related to the density of social connections. In contrast, the low-educated individuals turn to placement intermediaries, who give them free access to offers appropriate to their level of qualification (Lizé, 2000).

Under these conditions, economic theory teaches us that members of this category of the labor force migrate to the informal sector where they form social networks, which are an integral part of the social capital used to obtain access to employment. Thus, they establish horizontal relationships between individuals of the same group (family, friends, households, ethnic groups) and within social networks (groups of individuals, organizations that have common activities and purpose). They can also establish vertical relationships within organizations from different sectors, such as cooperatives, NGOs, local associations, and state agencies; with these relationships, a "network of networks" develops. In this approach, 
social capital has a microeconomic character. However, another approach argues that social capital has a macroeconomic character because the social and political environment involves the state (North, 1990), which Pantoja (1999) describes as political capital.

In the case of market intermediation, applications are unsolicited and are provided in response to classified advertisements. The access and job-search costs of classified advertisements are minimal, but imply great uncertainty about the characteristics of the candidates. The publication of advertisements in the press may be more expensive than other approaches, but because of the abundance of applications, it very quickly becomes profitable. Even if the company does not retain all of the responses, it can easily sort through the candidates and sometimes build up a reserve of the most interesting ones. These two procedures mainly follow a market logic insofar as the conflict between supply and demand for work is not disturbed by any external agent. Job seekers can respond to these advertisements or submit an application without discrimination at the outset. Ex ante, these job offers are anonymous for the company. In this case, the intermediaries make it possible to limit the risk of adverse selection.

Moreover, when the intermediary forms a partnership with employers by participating in the definition of the selection criteria for the job offers, a rather intensive search can be performed Sabatier (2003).

In contrast to neoclassical theory, neo-Keynesian theories exploit other indicators to interpret the correlation between education and job search intensity. According to the sorting models, a number of factors are involved in educational choices, productivity variation, and wage determination. There are two main competing approaches to human capital theory: filter theory and signal theory.

Filter theory, first proposed by Arrow (1973), suggests that the hiring decision is based on the candidate's level of education, not as a measure of potential productivity but rather as an indicator used only to sort among different candidates prior to hiring; according to this theory, education does not make the individual more productive. In the same sense as Arrow (1973), Spence (1974) postulates that the level of education plays a filtering role since it allows the identification of the most productive individuals. Thus, employers, not knowing the abilities of job applicants, look for all the skills they possess and claim that these skills are revealed by a signal given by the level of training.

For the proponents of the filter theory, the population is heterogeneous even before entering training because training costs differ from one individual to another. These training costs would be lower among the most gifted; this runs contrary to the theory of human capital, in which heterogeneity results from the accumulation of the capital of individuals who originally had similar aptitudes. Continuing in the same direction, signal theory addresses the consequences of asymmetric information regarding the individual strategies of economic agents in a situation of uncertainty.

Faced with a lack of information about the candidate's actual skills at the time 
of hiring, the employer takes into account two categories of observable variables: 1) unalterable characteristics (such as gender, age, skin color, etc.), referred to as indices, and 2) other characteristics that can be controlled by the individual (such as the level of human capital), referred to as signals. On the basis of previous experience, the employer proceeds to construct correspondences between skill signals and real, assumed or anticipated productivity indices arising from wage and occupational disparities between individuals.

Of the reported models, the model of competition for employment (Thurow, 1975) stands out. This model considers an alternative explanation of the labor market regulation mechanism as a substitute for the hypothesis of competition through wages. According to this model, the labor queue phenomenon is the result of employers' expectations of lowering their training costs by giving preference to candidates that will require lower training costs. The characteristics of the workforce, such as the level of human capital, may therefore explain their position in the queue for access to certain jobs. To this end, the level of education appears to be a tool used by job seekers and employers. For the former, the level of education acts as a signal that can reveal aptitudes; for the latter, it acts as a filter to identify the most suitable individuals to recruit for available jobs.

However, no theoretical explanation can a priori unambiguously establish the impact of the level of education on access to employment, especially among job seekers with similar levels of education. The pursuit of education may encourage young people to increase their reservation wage and to refuse certain jobs that nongraduates may accept, thus increasing their duration of access to employment. On the other hand, with more education and increasing age, job seekers may be better able to cope with the job search. Age and experience in the labor market increase the productivity of the search, as the individual is not only better informed when already integrated into the labor market but also more efficient in the art of selecting offers or presenting themselves at job interviews.

The theory of competition for jobs (Thurow, 1974) appears to be a variant of filter theory insofar as the skills needed for a job are acquired on the job. Work experience, especially membership in the firm, is valued by the employer, and the diploma is justified because it represents an indicator of the attitude to towards training. However, the young person leaving the education system without work experience is placed in the queue.

In contrast to previous theories, segmentation theory is more oriented towards the structure of the labor market. The question of the duality of the labor market was first addressed in the neoclassical movement by Lewis (1954), who proposed an economic model that took into account population movements and presented the economy of developing countries (DCs) as a dualist system in which a traditional sector (agriculture) in which labor productivity is close to zero coexists with a modern sector (industry) in which productivity is increasing and positive due to the accumulation of capital.

Since the industrial wage is higher than the agricultural wage, a geographical 
transfer of surplus agricultural labor to the modern sector is then initiated. In this framework, job creation in the modern sector would lead to a decrease in unemployment. The lack of realism in this approach has given way to other models that take underemployment into account. Todaro (1969) and Harris and Todaro (1970) challenged the predictions of the Lewis model by arguing that job creation in the modern sector would have the perverse effect of increasing the level of urban unemployment (Todaro's paradox) by creating a recruitment effect that attracts new migrants.

Indeed, in this model, the incentives to migrate represent the response to the urban-rural wage differential. The authors attempted to link job search theory and migration theory to account for incentives to migrate by taking into account a transition period for obtaining urban employment. Following the Harris-Todaro model of probabilistic behavior, Fields (1990) introduces the urban informal sector and then postulates (Fields, 1990) segmentation within the informal sector itself (into lower and upper segments).

Through the opposition between the formal and informal sectors, Fields highlights new developments. Indeed, segmentation theory divides the labor market into two markets, the primary market and the secondary market, which are themselves divided into several components (Doeringer and Piore, 1971). Experience and learning are favored by employers and are generally better paid, especially in the primary sector.

The level of education is used as a selection tool for entry into the different markets, but recruitment is most often based on rules established in each company, and the strongest component of competence is usually acquired through on-the-job training. Thus, Vernieres (1997) points out that young people with little experience are, in these conditions, expelled to secondary labor markets, where professional stability is elusive.

\section{Empirical Review}

This empirical review provides a large body of literature specifically highlighting employment access and job search conditions for young people. Thus, according to the pioneering work formalized by Arrow (1973) following the work of Berg (1970), productivity is completely disconnected from the level of human capital acquisition, unlike in Spence (1974). For the latter, individuals can be differentiated according to two criteria, namely, indices that relate to their personal characteristics. These characteristics appear as the points of difference between individuals in the labor market.

Thus, Gravot (1993) emphasizes that the integration of young people ultimately depends on acceptance by the employer and is therefore affected by the latter's behavior. In the same vein, several empirical works on youth integration seem to confirm the existence of a spatial segmentation of the youth labor market (Allaire, 1993; Allaire et al., 1995; Allaire and Tahar, 1996). National effects are also crucial if a global vision of youth integration is desired. Educational policies 
and public measures to assist integration are of prime importance not only in the competition between young people but also between generations (Germe, 1986).

Nevertheless, some young people can quickly access stable employment and benefit from the effects of chance (Béduwé \& Espinasse, 1996). Thus, while a diploma is one of the important factors in the integration of young people into the labor market, education is an economic investment that increases workers' productivity skills (Becker, 1964). Becker (1964) establishes a positive relationship between an individual's level of education and their probability of finding a job and obtaining a high wage in the labor market. Thus, Emmanuelle and Magda (2002) find that a degree reduces the risk of unemployment and promotes access to skilled and well-paying jobs.

This finding is confirmed by the results of the employment survey conducted in France by the National Institute of Statistics and Economic Studies, INSEE (2001). Other studies have endeavored to demonstrate the importance of the diploma in the overall career salary. Indeed, a fairly high level of human capital also allows employees to remain in employment as long as possible (De la Fuente and Ciccone, 2002). François and Livio (2009) highlight the creativity and self-learning skills that should be promoted at different levels of education. For Boudarbat \& Boulet (2007), access to employment is associated with the father's profession because the children of executive parents are more likely to have access to employment.

However, these results obtained by Boudarbat \& Boulet (2007) hold true more for boys than for girls. Indeed, it is interesting to note that it is the sons and not the daughters of executive fathers who have higher employment opportunities (14.2\% of boys versus $10.0 \%$ of girls) Boudarbat \& Boulet (2007). Therefore, the profession of the father or guardian will have a positive influence on the access of vocational training graduates to employment.

In the case of vocational training graduates, Boudarbat \& Boulet (2007) showed that the speed of access to employment increases with age among women. Earlier, Boudarbat (2006) provided empirical evidence of this behavior among university graduates in Morocco by considering the choice between employment in the public sector (high wages) and employment in the private sector (lower wages). In addition, in analyzing the relationship between the experience, performance, and income of employees in US firms using a multinomial logit model, Abraham \& Medoff (1980) argued that experienced individuals with more education receive significantly higher wages than those with less education.

Furthermore, the results obtained by Wapoh (2013) reveal that the social network is the most used and effective channel through which graduates obtain stable employment. Graduates use social networks more than proportionally to their use of institutional intermediaries, which are used more by women and less by graduates. Therefore, work experience facilitates access to stable employment and encourages the use of social networks. 


\section{Methodology}

The methodological framework of this work is inspired by the work of Bessy and Larquier (2010) and Bessy, Marchal and Rieucau (2007), who proposed separately studying the influence of job search methods on the labor market (formal and informal) and on contracts (fixed-term and permanent contracts). Given that the present work focuses on the modes of access to employment for young people in the Congo, we take the liberty of fully adopting the approach proposed by Ngassa (2018) on the dissociation of the employment sector into two subsectors (formal and informal). Thus, we use access to employment as an endogenous variable to analyze the effect of a job search method on access to this market. This model of individual behavior reflects the relationship between the labor market, human capital and societal integration strategies. This leads to the use of a dichotomous model where the latent dependent variable is unobservable. The dependent variable is then equal to 1 if the individual has access to employment and equal to 0 if not.

Using this approach, and assuming that the probability of working in the formal or informal sector is not correlated with the probability of using social networks or institutional intermediaries, we modeled an employment access equation that we separated into formal and informal sectors.

The probit model was formalized as follows:

On the one hand,

$$
X(i)=\alpha_{0}+\left(\sum_{k=1}^{j} \alpha_{k} X_{k}(i)\right)+\varepsilon_{i}
$$

And on the other hand

$$
Y= \begin{cases}0 & \text { si } X \leq y_{0} \\ 1 & \text { si } X>y_{0}\end{cases}
$$

As a result, the probability $P_{i}$ that the individual will obtain employment ( $Y=$ 1) will be:

$$
\begin{gathered}
P_{i}=P(Y=1)=P\left(X>y_{0}\right)=P\left(\alpha_{0}+\sum_{k=1}^{j} \alpha_{k} X_{k}(i)+\varepsilon_{i}>y_{0}\right) \\
P_{i}=P(Y=1)=P\left(X>y_{0}\right)=P\left[\varepsilon_{i}>y_{0}-\alpha_{0}-\left(\sum_{k=1}^{j} \alpha_{k} X_{k}(i)\right)\right] \\
P_{i}=P(Y=1)=P\left(X>y_{0}\right)=P\left[\varepsilon_{i} \leq \alpha_{0}+\left(\sum_{k=1}^{j} \alpha_{k} X_{k}(i)\right)-y_{0}\right] \\
P_{i}=P(Y=1)=P\left(X>y_{0}\right)=\varnothing\left[\alpha_{0}+\left(\sum_{k=1}^{j} \alpha_{k} X_{k}(i)\right)-y_{0}\right]
\end{gathered}
$$

With $\varnothing(\cdot)$, the distribution function of the law of $\varepsilon_{i}$.

Not knowing the distribution of $\varepsilon_{i}$, we are led to make assumptions about the distribution function $\varnothing(\cdot)$. We will thus refer to a logit model, a probit model or a Gumbel model depending on whether the distribution function used 
is a logistic distribution, a normal distribution or a Gumbel distribution.

The variables $y_{i 1}$ and $y_{i 2}$ represent the type of contract and the search mode for the job held, respectively. $x_{i 1}$ and $x_{i 2}$ are vectors of explanatory variables that describe the individual characteristics, geographical location, and occupation of the parents. $y_{i 1}^{*}$ and $y_{i 2}^{*}$ are the latent variables explained by the linear combination of $x_{i 1}$ and $x_{i 2}$.

\subsection{Data Source and Presentation of Variables}

The data for this article come from the Survey on the Improvement of Youth Employment Policies in Francophone Africa (EAPEJAF) conducted in 2018 by the (LARES) in the Republic of Congo. This survey targeted individuals of 15 to 35 years of age from three samples of 1000 young people, including 300 in Brazzaville and 700 in Pointe-Noire. The samples were categorized into three groups (placed in employment programs, not placed in employment programs and selected by household).

The sampling framework for the EAPEJAF was taken from the fourth General Census of Population and Housing (RGPH) of Congo in 2007. In total, there were 4.143 enumeration zones (ZDs), 2.258 of which were urban, 460 semiurban and 1425 rural.

In the survey data file, each ZD appears with all identifiers (department, commune/district, community/borough and identification code), the household size and number of residents, and the residence type (urban, semiurban or rural). Due to time and budget constraints, we used the household list from the Congo Multiple Indicator Cluster Survey (MICS Congo 2014-2015), which was updated in November-December 2014 throughout the country (Table 1).

After the survey, only 1981 individuals aged 15 - 34 were actually surveyed out of the planned 3000 . This represents a coverage rate of $66 \%$. The largest discrepancy was in the sample of employment program beneficiaries. Several reasons can be given for the low sample coverage. The main reason was the difficulty of tracing the beneficiaries of employment programs from the available databases, particularly for the years 2012, 2013, and 2014. There was also difficulty in

Table 1. Distribution of projected and surveyed population 15 - 34 years of age by interview type.

\begin{tabular}{ccccccc}
\hline & \multicolumn{3}{c}{ Projected } & \multicolumn{3}{c}{ Surveyed } \\
\cline { 2 - 7 } & Brazzaville & Pointe-Noire & Total & Brazzaville & Pointe-Noire & Total \\
\hline Interview type & & & & & & \\
PE: Beneficiaries & 350 & 650 & 1000 & 133 & 303 & 436 \\
PE: Nonbeneficiaries & 350 & 650 & 1000 & 89 & 697 & 786 \\
Household & 300 & 700 & 1000 & 379 & 418 & 806 \\
Total & 1000 & $\mathbf{2 0 0 0}$ & $\mathbf{3 0 0 0}$ & $\mathbf{6 0 1}$ & $\mathbf{1 3 8 0}$ & 1981 \\
\hline
\end{tabular}

Source: EAPEC (2018). 
constructing matched profiles of recipients and nonrecipients. These difficulties led to failures to follow the methodology recommended for constituting the sample. As a result, the size of some subgroups was adjusted upwards during the data collection process.

\subsection{Presentation of Variables}

The analysis of job access patterns involves several variables that can be grouped into two types (standard variables and job search variables). Table 2 first presents the standard variables used in this study.

Table 2 reveals that more than $60 \%$ of job seekers were male. With regard to age, young people between 25 and 35 years old dominated, accounting for 67\%

Table 2. Standard variables.

\begin{tabular}{|c|c|}
\hline Variable & Percentage \\
\hline \multicolumn{2}{|c|}{ Sex } \\
\hline Female & 34.76 \\
\hline Male & 65.24 \\
\hline \multicolumn{2}{|c|}{ Age } \\
\hline$[15-25[$ & 30.67 \\
\hline$[25-35[$ & 61.38 \\
\hline$[35-45[$ & 7.95 \\
\hline \multicolumn{2}{|c|}{ Job } \\
\hline Regular & 75.39 \\
\hline Occasional & 24.61 \\
\hline \multicolumn{2}{|c|}{ Enterprise size } \\
\hline 1 person & 22.56 \\
\hline 2 persons & 9.97 \\
\hline $3-5$ persons & 11.23 \\
\hline $6-10$ persons & 7.65 \\
\hline $11-20$ persons & 8.71 \\
\hline $21-50$ persons & 6.29 \\
\hline $51-100$ persons & 8.71 \\
\hline $101-500$ persons & 17.52 \\
\hline More than 500 persons & 7.36 \\
\hline \multicolumn{2}{|c|}{ Sector } \\
\hline Public & 7.37 \\
\hline Private & 83.96 \\
\hline Organization & 2.3 \\
\hline Personal & 6.36 \\
\hline \multicolumn{2}{|c|}{ Education } \\
\hline None/primary & 10.62 \\
\hline Secondary 1 & 25.8 \\
\hline Secondary 2 & 15.98 \\
\hline Postsecondary & 47.6 \\
\hline
\end{tabular}

Source: Authors of EAPEC (2018) survey. 
of the total, followed by those between 15 and 25 years old.

Table 3 shows that the "use of social capital" modality had the highest percentage at $60.58 \%$, followed by the "personal action" modality at $25.96 \%$. The "use of institutional channels" modality, which includes employment offices and employment agencies, accounted for only $13.46 \%$.

\subsection{Presentation and Interpretation of Results}

The estimation of the probit model presented in the table below shows that the probability of the Chi-square statistic (2) associated with the Wald statistic is significantly different from zero. This means that the model is significant overall. Finally, for each variable, the associated Wald test shows to what extent each independent variable is significantly related to the dependent variable.

Table 4 shows that the work type variable is significant in both formal and informal work, but the correlations have opposite signs. If it is less probable to find casual work than regular work in the formal sector, the situation is the opposite in the informal sector.

The gender variable is significant only in the formal sector, which shows that women are more likely to find employment than men. In the informal sector, this variable is not significant.

The firm-size variable is significant in both sectors from a firm of 6 people to more than 500 people, but the sign of the correlation is positive in the formal sector but negative in the informal sector. Therefore, a person is more likely to find employment in the informal sector than in the formal sector.

The activity sector variable is also significantly negatively correlated with the personal modality in the formal sector. This suggests that a self-employed person is less likely to find employment in the formal sector.

The job-search mode variable, which has three modalities, is significant in both the formal and informal sectors. Thus, social capital promotes access to employment in the informal sector more than institutions, whereas institutions promote access to employment in the formal sector.

It should be pointed out that the age and education level variables are not significant in the job market for Congolese youth. This is contrary to economic theory, which considers the level of education to be a signal within the labor market.

\section{Conclusion and Policy Implications}

The aim of this work is to analyze the different employment access and job

Table 3. Job search methods.

\begin{tabular}{cc}
\hline Variable & Percentage \\
\hline Use of social capital & 60.58 \\
Use of institutional channels & 13.46 \\
Personal action & 25.96 \\
\hline
\end{tabular}

Source: Authors of EAPEC (2018). 
Table 4. Marginal effects model results.

\begin{tabular}{|c|c|c|c|}
\hline Variable & Modality & Formal (Dx/dy) & Informal (Dx/dy) \\
\hline \multirow{3}{*}{ Type of job } & Regular (ref.) & & \\
\hline & Occasional & -0.016 & 0.187 \\
\hline & & $(-5.32)^{* * *}$ & $(5.57)^{* * *}$ \\
\hline \multirow{3}{*}{ Sex } & Female & & \\
\hline & Male & -0.073 & 0.024 \\
\hline & & $(-3.04)^{\star * *}$ & $(0.90)$ \\
\hline \multirow{17}{*}{ Enterprise size } & 1 person (Ref.) & & \\
\hline & 2 persons & -0.054 & -0.074 \\
\hline & & $(-0.30)$ & $(-0.131)$ \\
\hline & $3-5$ persons & 0.045 & -0.038 \\
\hline & & -1.54 & $(-0.71)$ \\
\hline & $6-10$ persons & 0.191 & -0.020 \\
\hline & & $(4.17)^{\star * *}$ & $(-3.22)^{* * *}$ \\
\hline & $11-20$ persons & 0.316 & -0.298 \\
\hline & & $(6.51)^{\star * *}$ & $(-4.86)^{\star * *}$ \\
\hline & $21-50$ persons & 0.415 & -0.417 \\
\hline & & $(6.76)^{* * *}$ & $(-12.08)$ \\
\hline & $51-100$ persons & 0.650 & -0.651 \\
\hline & & $(12.74)$ & $(-15.13)$ \\
\hline & $101-500$ persons & 0.659 & -0.651 \\
\hline & & $(17.11)^{\star * \star}$ & $(-15.13)^{\star * \star}$ \\
\hline & More 500 persons & 0.671 & -0.518 \\
\hline & & $(11.38)^{\star * \star}$ & $(-7.71)^{\star * \star}$ \\
\hline \multirow{5}{*}{ Age } & {$[15-25[$} & & \\
\hline & {$[25-35[$} & 0.034 & -0.066 \\
\hline & & $(1.03)$ & $(-2.01)$ \\
\hline & {$[35-45[$} & 0.059 & -0.001 \\
\hline & & $(1.35)$ & $(-0.03)$ \\
\hline \multirow{7}{*}{ Education } & Without/primary (Ref.) & & \\
\hline & Secondary 1 & 0.016 & 0.073 \\
\hline & & $(0.41)$ & (1.69) \\
\hline & Secondary 2 & -0.060 & 0.054 \\
\hline & & $(-1.21)$ & $(1.05)$ \\
\hline & Postsecondary & 0.017 & -0.021 \\
\hline & & $(0.46)$ & $(-0.51)$ \\
\hline
\end{tabular}




\section{Continued}

\begin{tabular}{|c|c|c|c|}
\hline \multicolumn{4}{|c|}{ Public (Ref.) } \\
\hline \multirow{6}{*}{ Activity sector } & \multirow[t]{2}{*}{ Private } & 0.040 & 0.009 \\
\hline & & $(1.15)$ & $(0.18)$ \\
\hline & \multirow[t]{2}{*}{ Organization } & -0.102 & 0.021 \\
\hline & & $(-0.90)$ & $(0.23)$ \\
\hline & \multirow[t]{2}{*}{ Personal } & -0.217 & 0.156 \\
\hline & & $(-2.65)^{\star *}$ & $(1.45)$ \\
\hline \multirow{5}{*}{ Job search method } & \multicolumn{3}{|l|}{ Social capital (Ref.) } \\
\hline & \multirow[t]{2}{*}{ Institutional } & 0.111 & -0.097 \\
\hline & & $(3.40)^{* * *}$ & $(-2.29)^{* * *}$ \\
\hline & \multirow[t]{2}{*}{ Personal action } & -0.006 & -0.006 \\
\hline & & $(-0.25)$ & $(0.22)$ \\
\hline \multirow{2}{*}{\multicolumn{2}{|c|}{ Constant }} & -2.208 & 0.701 \\
\hline & & $(5.93)^{\star *}$ & $(2.37)^{\star}$ \\
\hline \multicolumn{2}{|l|}{ Number of observations } & 986 & 986 \\
\hline \multicolumn{2}{|c|}{$\mathrm{R}^{2}$} & 0.4736 & 0.358 \\
\hline \multicolumn{2}{|c|}{ LR chi2 (20) } & $602.85(0.0000)$ & $487.99(0.0000)$ \\
\hline \multicolumn{2}{|c|}{ ROC } & 0.916 & 0.871 \\
\hline
\end{tabular}

${ }^{\star} \mathrm{p}<0.01 ;{ }^{* *} \mathrm{p}<0.05 ;{ }^{* *} \mathrm{p}<0.1$. Source: authors of (EAPEC, 2018) survey.

search channels in Congo using data from the survey conducted by the Laboratoire de Recherches et d'Études Economiques et Sociles in 2018. The results obtained after econometric analysis using the bivariate probit model revealed that in Congo, as in other developing countries, social networks are the channel through which young people access employment. This corroborates the findings of the ILO (2019) report. In addition, the results showed that the informal sector offers more employment than the formal sector. These results have allowed us to formulate some economic policy implications regarding employment access and job search channels for young people in the Congo. These policy implications suggest matching training and employment, improving the Congolese productive system, and improving governance and intermediation in the labor market and employment support structures.

With regard to training and employment matching, Congo is an oil-producing country, but its quality of human capital is poor. Indeed, according to the World Bank report (2016), in ten French-speaking African countries, 71\% of children in second grade do not have a sufficient level of French and are unable to understand clear information given orally or the meaning of a series of written words. In addition, 59\% of fifth-grade students are too weak in mathematics to be able to perform operations with decimals or to identify a simple mathematical formula to solve a problem. The poor quality of human capital can be justified by 
the low level of investment of oil revenues in education, specifically in employment training programs, and poor governance. Thus, because they have received low-quality training, young people have no choice but to turn to the informal sector, which is less selective than the formal sector.

With regard to improving the Congolese productive system, the Congolese economy is based on oil production, which accounts for $90 \%$ of exports (Initiative pour la Transparence dans les Industries Extractives, ITIE, 2018). This is characteristic of an economy with concentrated exports and therefore little diversification. The Congolese economy is therefore a victim of Dutch disease, and diversifying the economy would allow Congo to follow the classical pattern of structural transformation. Consequently, many jobs would be created in the three sectors (primary, secondary and tertiary).

However, as in many oil-producing developing countries, the poor management of oil revenues does not allow improved governance or intermediation in the labor market and employment support structures. Indeed, according to ITIE (2018), part of the revenues from the marketing of state oil shares is used as a guarantee against default on the repayment of infrastructure projects financed by China. It should be noted that a cash consideration for the sale by the Sociéte Nationale des Pétroles du Congo (SNPC) of a gross quantity taken from the State's oil shares is not paid into the account of the Public Treasury but into a specific escrow account. The management of this transaction is completely opaque. Indeed, the quantities of oil, the details and nature of the infrastructure projects, and the details of the agreement (amount, period, investment cost, repayment terms) have not been communicated to the public ITIE (2018).

\section{Conflicts of Interest}

The authors declare no conflicts of interest regarding the publication of this paper.

\section{References}

Abraham, K. G., \& Medoff, J. L. (1980). Experience, Performance and Earning. Quarterly Journal of Economics, 95, 703-736. https://doi.org/10.2307/1885488

Allaire, G. (1993). Structure territorial des emplois ruraux, colloque agrotech dynamique des espaces ruraux, agriculture et environnement (37 p.).

Allaire, G., \& Tahar, G. (1996). L'insertion professionnelle des jeunes urbains ou ruraux de bas niveau scolaire. Revue d'Économie Régionale et Urbaine, 2, 309-328.

Allaire, G., Beslay, C., Chartier, R., \& Tahar, G. (1995). Modélisation des trajectoires d'insertion selon quatre phases. Communication à la 3e Journée d'Étude du CLERSE L'insertion professionnelle, nouvelles approches, nouveaux débats. Lille, 7 juin.

Arrow, K. (1973). The Theory of Discrimination. In O. A. Ashenfelter, \& A. Rees (Eds.), Discrimination in Labor Markets (pp. 3-33). Princeton, NJ: Princeton University Press.

Baudry, B. (1994). Segmentation du marché du travail et segmentation du marché de la sous-traitance: Une étude de la firme réseau. Revue d'économie politique, 104, 75-95.

Becker, G. S. (1964). Human Capital (2nd ed.). New York: Columbia University Press. 
Béduwé, C., \& Espinasse, J.-M. (1996). Concurrences entre générations et accès à l'emploi des jeunes, Formation-Emploi, 55. https://doi.org/10.3406/forem.1996.2158

Berg, I. (1970). Education and Jobs: The Great Training Robbery (194 p.). New York: Praeger Publishers.

Bessy, C., \& Larquier, G. (2010). Diversité et efficacité des intermédiaires du placement. Revue française d'économie, 25, 227-270. https://doi.org/10.3406/rfeco.2010.1809

Bessy, C., Marchal, E., \& Rieucau, G. (2007). L'importance des candidatures spontanées en France. Connaissance de l'emploi.

Boudarbat, B. (2006). Unemployment, Status in Employment and Wages in Morocco. Applied Econometrics and International Development, 6, 165-184.

Boudarbat, B., \& Boulet, M. (2007). Détérioration des salaires des nouveaux immigrants au Québec par rapport à l'Ontario et à la Colombie-Britannique. Choix-IRPP, 13, $34 \mathrm{p}$.

Bull, C., Ornati, O., \& Tedeschi, P. (1987). Search, Hiring and Labour Market Intermediaries. Journal of Labour Economics, 5, 1-17. https://doi.org/10.1086/298162

Clark, A. E. (1999). Les méthodes de recherche d’emploi des chômeurs dans les pays de I'OCDE. Paris: Rapport OCDE.

De la Fuente, A., \& Ciccone, A. (2002). Le capital humain dans une économie mondiale sur la connaissance. Rapport pour la Commission Européenne.

Doeringer, P., \& Piore, M. (1971). Internal Labor Markets and Manpower Analysis (214 p.). Heath Lexington Books, Seconde édition augmentée, 1985, Armonk: Sharpe, N-Y.

Emmanuelle, N.-F., \& Magda, T. (2002). Diplôme et insertion sur le marché du travail: Approches socioprofessionnelle et salariale du déclassement suivi d'un commentaire de Saïd Hanchane et Eric Verdier. Economie et statistique, 354, 21-48. https://doi.org/10.3406/estat.2002.7383

Enquête sur l'Amélioration des Politiques d'Emploi au Congo (EAPEC) (2018). UMNGFSE-LARES, Brazzaville.

Fields, G. S. (1990). Labour Market Modeling and the Urban Informal Sector: Theory and Evidence. In D. Turnham, B. Salomé, \& A. Schwarz (Eds.), The Informal Sector Revisited (pp. 49-69). Paris: Organization for Economic Co-Operation and Development.

François, T., \& Livio, R. S. (2009). Proposing Measures to Promote the Education of Creative and Collaborative Knowledge-Builders. OCDE.

Germe, J. F. (1986). Modalité et identification des salaries (pp. 357-370). Paris: Economica.

Granovetter, M. S. (1973). Getting a Job. Cambridge, MA: Harvard University Press.

Gravot, P. (1993). Économie de l'éducation (244 p.). Paris: Economica.

Harris, R., \& Todaro, M. (1970). Migration, Unemployment and Development: A Two Sector Analysis. American Economic Review, 60, 126-142.

ILO (2019). World Employment Social Outlook Trends. https://doi.org/10.1002/wow3.150

Initiative pour la Transparence dans les Industries Extractives ITIE (2018). Congo Rapport de cadrage.

INSEE (2001). Enquête sans-domicile, Méthodes No. 116.

Lewis, A. W. (1954). Economic Development with Unlimited Supplies of Labor. The Manchester School of Economic and Social Studies, 22, 139-191. https://doi.org/10.1111/j.1467-9957.1954.tb00021.x

Lizé, L. (2000). Politiques de recrutement des entreprises et aides à l'emploi: Quel rôle pour l'ANPE? Travail et employ, 83, 97-114. 
Marry, C. (1992). Les jeunes et l'emploi: Force et faiblesse des liens forts. In L. Coutrot, \& C. Dubar (Eds.), Cheminements professionnels et mobilités sociales (pp. 299-324). Paris: La Documentation française.

Moreau, A., \& Visser, M. (1991). Durée du chômage des jeunes en France. Annals of Economics and Statistics, GENES, No. 20-21, 257-278. https://doi.org/10.2307/20075815

Mortensen, D. T. (1970). Job Search, the Duration of Unemployment, and the Phillips Curve. American Economic Review, 60, 505-517.

Ngassa Ted Cleophane (2018). Effets du capital social sur l'accès à l'emploi au Congo. Thèse de doctorat, Université Marien Ngouabi.

North, D. C. (1990). Institutions, Institutional Change, and Economic Performance. Cambridge: Cambridge University Press. https://doi.org/10.1017/CBO9780511808678

Pantoja, E. (1999). Exploring the Concept of Social Capital and Its Relevance on the Community-Based Development, Social Capital Intuitive (pp. 94-105). Working Paper No. 18, Washington DC: World Bank.

Phelps, E. S. et al. (1970). Microeconomic Foundations of Employment and Inflation Theory. New York: W. W. Norton and Co.

Rees, A. (1966). Information Networks in Labor Markets. American Economic Review, 56, 559-566.

Sabatier, M. (2003). Stratégie d'Insertion et Durée d'Accès au Premier Emploi. Revue d'économie politique, 113, 671-696. https://doi.org/10.3917/redp.135.0671

Sara, E., \& Koné, K. S. (2014). Transition vers le marché du travail des jeunes femmes et hommes en Afrique subsaharienne. Work 4 Youth Série de publication No. 10, Genève: BIT.

Spence, M. (1974). Market Signaling: Informational Transferring in Hiring and Related Screening Processes. Cambridge, MA: Harvard University Press.

Stigler, G. (1962). Information in the Labor Market. Journal of Political Economy, 70, 94-105. https://doi.org/10.1086/258727

Thurow, L. (1974). Cash versus In-Kind Transfers. American Economic Review, 64, 190 195.

Thurow, L. C. (1975). Generating Inequality (258 p.). New York: Basic Books. https://doi.org/10.1007/978-1-349-15723-5

Todaro, M. P. (1969). A Model of Labour Migration and Urban Unemployment in Less Developed Countries. American Economic Review, 59, 138-148.

United Nations (2017). UN World Population Prospects: Key Findings and Advance Tables. Revision, New York.

Vernieres, M. (1997). L’insertion professionnelle, Analyse et débats. Paris: Economica.

Wadsworth, J. (1990). Unemployment Benefits and Search Effort in the U.K. Labour Market. Economica, 58, 17-34. https://doi.org/10.2307/2554973

Wapoh, H. (2013). Modes d'accès à l'emploi des diplômés en Côte d'Ivoire (pp. 691-723). In Economies et Sociétés, série "Socio-Economie du travail. AB, No. 35, 5/2013.

World Bank (2014). Youth Employment in Sub-Saharan Africa. Africa Development Series, Washington DC. 


\section{Annex: ROC Diagnostic Test Curve}

ROC FORMEL

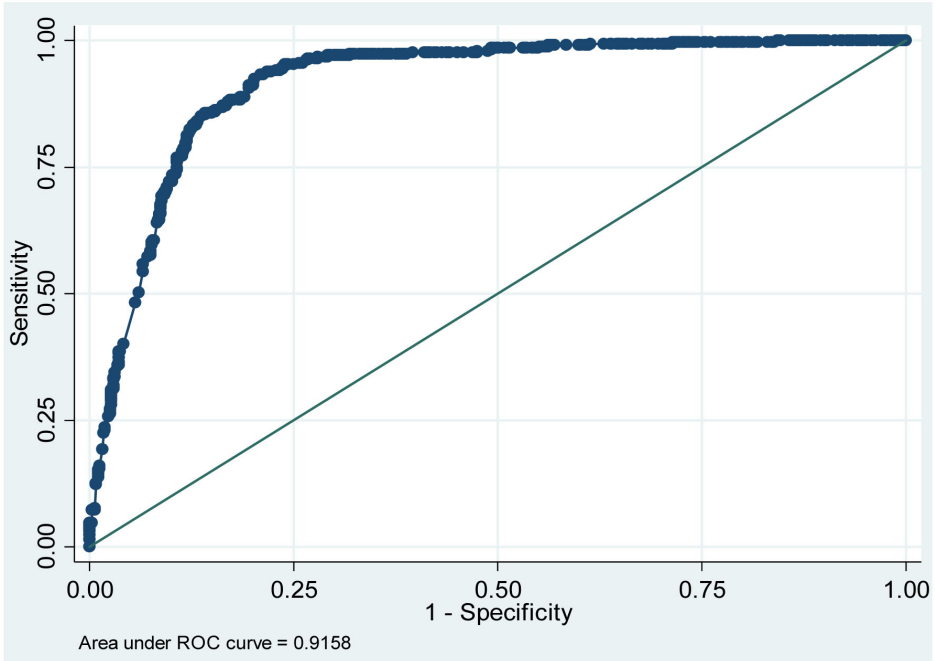

ROC INFORMEL

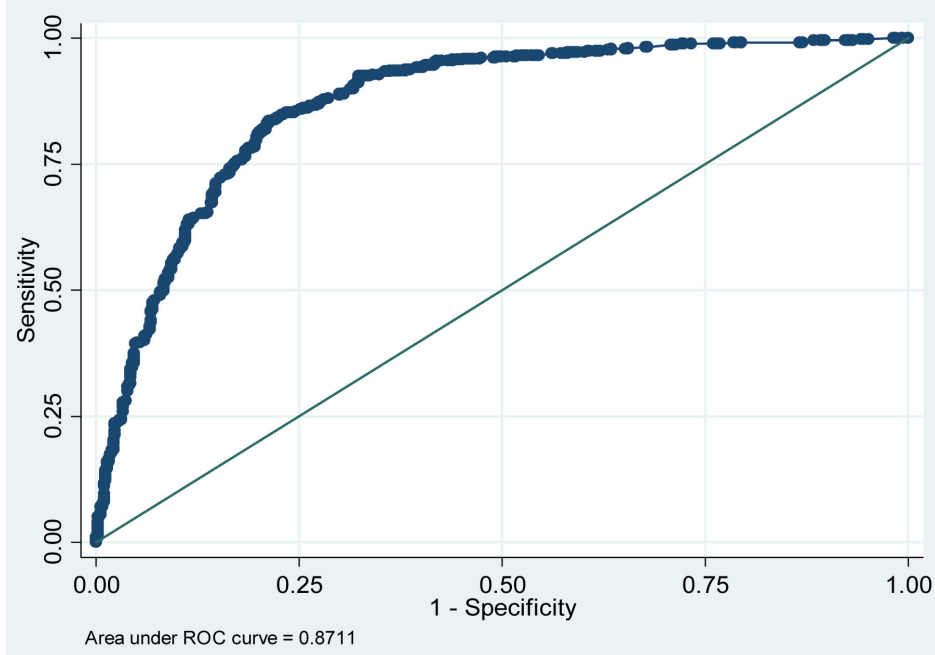

